Daniela Marčoková*

UDC 811.162.4'373232.1(497.113 Bačka)

Anna Makišová

DOI: $10.19090 / \mathrm{gff} .2018 .1 .359-372$

Filozofická fakulta

Univerzita v Novom Sade

\title{
PRÍMENÁ SLOVÁKOV V SLOVENSKÝCH OSADÁCH BÁČSKOPETROVSKEJ OBCE ${ }^{* *}$
}

Predmetom výskumu bola neúradná pomenovacia sústava obyvatel'ov slovenských osád v báčskopetrovskej obci, a to tých, ktorí sú slovenskej národnosti. Ciel’om výskumu bolo evidovat' prímená dospelých obyvatel'ov mužského pohlavia, ktoré sa vyskytovali v druhej polovici 20. storočia, na prelome tisícročí a tie, ktoré sa dodnes používajú v každodennej komunikácii v osadách Báčsky Petrovec, Hložany a Kulpín. Vo výskume sme uplatnili metódu živej pamäti. Výsledky nášho výskumu môžeme zhrnút' takto: v Báčskom Petrovci sme zaznamenali 432 prímen; v Hložanoch 299 prímen a v Kulpíne 94 prímen.V každej osade bolo najviacej prímen vyvodených z vlastného mena a priezviska, potom podl’a funkcie, zamestnania a vykonávania činnosti a nakoniec podl'a psycho-fyzických vlastností a stavov. Pri existujúcich prímenách sme si všimli vplyv nárečia, vplyv srbského jazyka, ako i príklon k inojazyčným osobným menám. Prímená považujeme za výraz historickej informácie a za súčast’ kultúrneho a tradičného dedičstva.

Klúčové slová: onomastika; slovenské osady Báčsky Petrovec, Hložany, Kulpín; dolnozemská kultúrna a tradičná špecifickost'

Prímená ukrývajú zaujímavé informácie o l’ud’och, ich kultúre a spôsobe života $\mathrm{v}$ určitom regióne, a preto sú zaujímavým humánno-geografickým objektom výskumu. Podobne ako je to s priezviskami, tak i priestorové rozmiestnenie prímen môže byt' determinované rôznymi demografickými a geografickými faktormi a na ich základe možno sledovat' kultúrny vývoj daného miesta či regiónu. Prímená sú všeobecným jazykovým javom vo všetkých národoch. Vznikali od najstarších čias po súčasnost' a preto ich možno považovat' za výraz historickej informácie. Slovenské vojvodinské prímená považujeme za súčast' slovenského kultúrneho a

\footnotetext{
*danielamarcokova@ff.uns.ac.rs

** Príspevok vznikol v rámci projektu č. 178017 Diskurzy menšinových jazykov, literatúr a kultúr v juhovýchodnej a strednej Európe, ktorý financuje Ministerstvo osvety, vedy a technologického rozvoja.
} 
tradičného dedičstva. Zaslúžia si našu pozornost', pretože „ako jeden z prejavov zakoreňovania slovenských kolonistov v novom prostredí, nesú v sebe aj znaky neopakovatel'nej dolnozemskej, regionálnej a lokálnej špecifickosti" (Botík, 2011: 139).

Prví Slováci sa z Hornej zeme na územie dnešnej Vojvodiny v najväčšom počte st'ahovali koncom 18. storočia. Najprv osídl'ovali Báčku, potom Banát a Sriem. J. Botík poukazuje na potrebu vzniku prezývok $\mathrm{v}$ dolnozemskom slovenskom prostredí. Slovenskí kolonisti si prinášali nielen jazykovú a kultúrnu výbavu, ale aj rodovú tradíciu a rodinnú identitu, svoje priezviská, no ked’ sa rodiny rozvetvili, priezviská prestali plnit' svoju identifikačnú funkciu. Potreba nezamenitel'ného označenia príslušníkov týchto rozvetvených rodín si vynucovala, aby sa k priezviskám pridávali rôzne prezývky (2011: 139).

Predmetom nášho výskumu bola neúradná pomenovacia sústava obyvatel’ov Báčky, ${ }^{1}$ ktorí sú slovenskej národnosti. Vzhl'adom na priestorovú obmedzenost' tohto príspevku, výskumom nemôžeme zahrnút' všetky sídla v Báčke obývané Slovákmi. Ciel’om nášho výskumu bolo evidovat' prímená dospelých obyvatel'ov mužského pohlavia slovenskej národnosti zo slovenských osád báčskopetrovskej obce (jedinej slovenskej obce v Srbsku), ktorá zahrňuje osady: Báčsky Petrovec, Hložany a Kulpín. Zaujímali nás aj osobné a rodinné prímená, ktorých nositelia už nežijú v týchto osadách, alebo už nežijú vôbec, alebo i prímená, vzt’ahujúce sa na priezviská, ktoré v týchto osadách zanikli.

Informátori boli zámerne volené osoby, u ktorých sme predpokladali, že poznajú väčšinu obyvatel'stva svojej osady. Materiál sme získavali vlastným terénnym výskumom v rokoch 2016 a 2017. Vo výskume sme uplatnili metódu živej pamäti (podobné termíny sú kolektívna a komunikatívna pamät').

\section{MENO - PRÍMENO (PREZÝVKA) - PRIEZVISKO}

Dávanie mena a priezviska novorodencovi je v každom štáte regulované zákonom. V úradnom styku sa u Slovákov uplatňuje dvojmenná sústava osobných mien, pozostávajúca z osobného mena (krstné, rodné meno) a priezviska (dedičné rodinné meno). Predchodcami priezvisk boli prímená, ktoré okrem mena mali

\footnotetext{
${ }^{1}$ Sídla v Báčke, v ktorých žijú Slováci, uvedené abecedným poradím: Báčska Palanka, Báčsky Petrovec, Bajša, Begeč, Čelárevo, Hložany, Kulpín, Kysáč, Lalit', Nový Sad, Pivnica, Selenča, Silbaš (Sklabinská, Mosnáková, 2012).
} 
najprv iba šlachtici v 15. a 16. storočí, neskoršie meštania a poddaní na dedinách v 16. a 17. storočí (Dudok, 1998:17).

Podl'a S. Csachovej je slovo priezvisko odvodené od slova prezývka a začalo sa používat' na lepšie odlíšenie človeka vo verejnom styku na území Slovenska od 18. storočia, ked' sa za vlády Jozefa II. uskutočnilo sčítanie l’udu a vtedy sa meno a priezvisko stali úradne záväznou informáciou (2015: 101). Pôvodne vznikali priezviská podl’a dedinskej nadávky, prezývky, podl’a telesných a duševných vlastností, podla bydliska, miesta pôvodu otca alebo matky, prípadne podl'a názvu živočíchov, rastlín či neživých predmetov. V 18. storočí Slováci prichádzali na územie dnešnej Vojvodiny a v matrikách dolnozemských cirkevných zborov nachádzame už iba dvojmennú pomenovaciu sústavu.

V. Blanár považuje neúradné a poloúradné pomenúvanie (tzv. živé mená) za pomerne samostatný podsystém. „Kým v úradných onymických sústavách (ich základná podoba je písaná) sa používajú úradne kodifikované, štandardizované podoby mien, pre neúradné sústavy, ktorých základná je podoba hovorená, sú charakteristické variantné, často nárečovým blízke podoby mien. Živé mená odlišuje od úradného pomenúvania ustálenost' užším spoločenským úzom” (2008: $50)$.

V skúmanej literatúre sa termíny prímeno (prídomok, predikát) a prezývka chápu rôzne. Podla Krátkeho slovníka slovenského jazyka prímeno je d’alšie meno pridané k priezvisku (1989: 352) a prezývka je vedl'ajšie pomenovanie niekoho podl'a charakteristických vlastností (1989: 347). V Synonymickom slovníku slovenčiny pri hesle prezývka sa uvádzajú synonymá: nadávka, zahrešenie, zakliatie, urážajúce pomenovanie a hrubý výraz. V našom výskume budeme používat' termín prímeno. Niekedy prímeno bolo utvorené na základe bud’to nadávky alebo nejakého urážajúceho pomenovania, ale predmetom nášho výskumu nie je spôsob tvorenia prímen.

\section{VÝSKUM V OBLASTI ONOMASTIKY V RÁMCI SLOVENSKÉHO VOJVODINSKÉHO PROSTREDIA}

Problematika vlastných mien Slovákov vo Vojvodine nie je zatial' dostatočne preskúmaná. Najčastejšie sa slovenskí vojvodinskí bádatelia venovali výskumy priezvisk, ojedinele sa vyskytujú aj výskumy prímen. D. Dudok (1998) sa najkomplexnejšie venoval onomastickým výskumom v našom prostredí. Preskúmal priezviská Slovákov vo Vojvodine a okrem iného sa venoval i vysvetleniu pôvodu a významu 4200 priezvisk. A. Marićová vo svojej práci skúmala pôvod a funkciu neúradného priezviska staropazovských Slovákov, ktoré nemožno stotožnit' ani 
s prezývkou, ani s prímenom. Do mennej sústavy neúradné priezvisko vstupuje v období založenia Starej Pazovy na Vojenskej hranici, kde Slováci žili v domových spoločenstvách, tzv. zádrugách, založených na príbuzenskom pokrvnom zväzku (2015: 79-86). J. Kováč knižne spracoval problematiku dvojakých priezvisk v Starej Pazove a iba okrajovo uvádza prímená a prezývky (2002: 19).

Prímená (prezývky) v Pivnici do roku 1970 zaznamenala Z. Týrová (2005: 175-179). Tiež sa venovala i otázke vzniku niektorých prezývok a otázke odzrkadl'ovania cudzojazyčných prvkov na slovenské prezývky v multikultúrnom prostredí. J. Botík v rámci svojej práce tiež zaznamenal prezývky Pivničanov (2011: 139-141). Hoci nepodal numerický prehl'ad, zistili sme, že zaznamenal 82 priezvisk s 228 prezývkami.

D. Marčoková a A. Makišová sa zaoberali výskumom prímen v slovenskej osade Kysáč v Báčke. V minulosti boli pokusy o zaznamenávanie prímen miestnymi obyvatel'mi, no okrem rukopisu M. Párnického, iné súpisy sa nezachovali. Po takmer 50-ročnom časovom odstupe autorky zaznamenali šest'krát viac prímen a zistili, že v súčasnosti je 165 priezvisk (čo je asi štvrtina z úhrnného počtu slovenských priezvisk v Kysáči), pri ktorých sa vyskytuje až 742 prímen (2017: 291).

Ked’že výskumy tohto druhu v slovenských vojvodinských osadách boli vykonané iba ojedinele, náš nový výskum svojím zameraním nadväzuje na predchádzajúci a jeho ciel’om je zaznamenat' prímená Slovákov v širšom regióne na území Báčky. V krátkosti uvádzame roky a okolnosti príchodu prvých Slovákov, ako i súčasný počet obyvatel'ov v skúmaných osadách.

\section{DATABÁZA ZAZNAMENANÝCH PRÍMEN V BÁČSKOM PETROVCI ${ }^{2}$}

Petrovec vznikol na území futockého panstva ned’aleko Nového Sadu. Prví slovenskí pristahovalci pochádzali z Novohradu, Hontu, ale i z osád Peštianskej stolice a doviedol ich sem slobodník Matej Čáni roku 1745. Dodnes je Petrovec najväčšia slovenská osada vo Vojvodine (Sirácky, 1980: 66-67). Podl’a Štatistického ústavu Republiky Srbsko v Báčskom Petrovci roku 2012 žilo spolu 6155 obyvatel'ov, z čoho bolo 4982 Slovákov.

\footnotetext{
${ }^{2}$ Informátori: Anna Melichová (rod. Melichová; nar. 1947), Ján Melich - Mél’o (nar. 1940), Pavel Brtka - Pápe (nar. 1965), Mária Vujovićová (rod. Beličková; nar. 1944), Daniela Vujovićová (nar. 1995)
} 
Roztriedenie prímen:

1. Podl'a mena (úhrnne 187):

a) vyvodené z vlastného mena (31): Ďuki, Ďuri, Eydi, Fero, Fet'ko, Janco, Jayči, Jani, Joki, Jovi, Karko, Lád’o, Miki, Mirdžo, Miri, Ondo, Ołko, Paki, Pal'ino, Pal'ko, Pato, Pet'o, Rále, Rášo, Rusti, Sájko, Sájo, Saki, Samul'o, Stenli, Toyko.

b) vyvodené z priezviska (119): Ándro, Áres, Bábo, Bádžo, Baki, Bále, Béli, Bél'o, Bene, Benkil'i, Bód’o, Bógo, Bori, Boško, Bŕle, Brt’o, Céro, Cíbe, Cini, Čéko, Č́l'o, Ďemro, Ďenko, Dígo Dijko, Dubac, Dudi, Faki, Gábo, Gayko, Gaški, Geci, Gédžo, Géjo, Gugi, Gúle, Háso, Hečko, Heụko, Chápo, Chlpi, Íto, Kébo, Kéjo, Kémo, Kévo, Koci, Koki, Kokso, Kóle, Kondi, Kori, Kóro, Kríle, Krndi, Krni, Kuki, Kúle, Kuške, Lábo, Lého, Leki, Léko, Lépo, Máko, Makso, Mandi, Médo, Megi, Mél’o, Meydo, Mici, Mikso, Mišt’o, Mlingco, Mrázik, Mundi, Oče, Očko, Opi, Opo, Pajgo, Pápo, Páre, Peki, Pet'o, Príco, Pucko, Rápo, Ripko, Róso, Sabík, Sélo, Sémo, Siki, Siri, Skl’enči, Slaụči, Sňitko, Speki, Stráko, Strunko, Šélo, Šlivi, Šubi, Súco, Taki, Tóco, Topol’ac, Trki, Tŕle, Tuki, Uške, Vali, Vrbík, Vrški, Zeki, Zélo, Zimko.

c) matronymiká (podl’a ženskej línie, t. j. priezviska manželky) (5): Benda, Faboụk, Fačara, Gájim, Katịak;

d) podl’a srbského mena/priezviska (11): Báne, Bobam, Čédo, Ďóko, Ď́ura, Kosta, Márko, Míto, Pájo, Radoje, Žáro;

e) podl'a cudzieho mena (21): Čarli (angl.), Džefro (angl.), Džeki (angl.), Džimi (angl.), Džíne (angl.), Džoni (angl.), Hasam(arab.), Ištván (mad'.), Janes (slo.), Johan (nem.), Juhás (mad'.), Laci (mad'.), Lajko (mad'. Lajoš), Migel (špan.), Pišta (mad'.), Pišt'iko (mad'.), Riki (angl.), Teri (angl.), Stípe (chor.), Šaňi (mad'.), Šošana (židovské ženské meno, z ktorého je odvodené meno Zuzana).

2. Podl’a geografického názvu, národného príslušenstva a priestorového rozmiestnenia (11): Čikago, Francús, Jenki, Sálašam, Sálašaňịa, Slovák, Srémac, Šošóm, Štajerac,Talịiam, Tokaji.

3. Zvieracieho pôvodu (8): Kešo (v minulosti časté meno koňa), Kuci (mad'. kutya - pes), Máčak (srb. mačak - kocúr), Murko (časté meno kocúra), Pátak (srb. patak - káčer), Róvac (srb. rovac - krtonôžka obyčajná),Tuňịak, Zéko (srb. zeko - zajko).

4. Rodinného pôvodu (9): Báto, Bat’o, Brat'ina, Kumko, Pápe, Ród’o, Svat, Ujco, Ujo. 
5. Podl’a názvov jedál a nápojov (4): Brendi, Bronchi, Šifl'ík, Žváka.

6. Cudzieho pôvodu (3): Bleki (angl. black - čierny), Euréka (heuréka - gr. „našiel som to"), Laki (angl. lucky - štastný).

7. Podl'a funkcie, zamestnania a vykonávania činnosti, názvu podniku (57): Bágerista, Bátkár (opravoval hrnce), Begejáš (údržbár, udržiaval potôčik Begej a okolie), Bochter (žil na železničnej stanici v domčeku - v bochterni), Bošista (opravoval motory), Bravčịar, Brdár (vyrábal čast' krosien - brdo), Cukráši (vyrábali cukrárske výrobky), Čižmadija, Darál'ovňík, Dekam, Dotúr (chcel byt' doktorom), Drevenkár, Farár, Geregár (pestoval melóny), Guvernér, Herec, Hod’inkár, Hrnčịar, Hrobár, Huci (hudec), Kemenári, Klamfár (pracoval s plechom), Kobasičár, Kolovratár, Krajčír, Krcko (hryzkal semienka, „krckav”), Krimi, Kuršmit (zverolekár), Kvapka (vodoinštalatér), Kušňịar (šil kožuchy), Lojtráš, Mad’ioničár, Majster, Malịar, Medár, Mercédes (podl’a názvu firmy), Meteorolók, Moňašịar (vlastnil kone), Muzikanti, Osigurant, Paprikár, Pipidoktor, Singer (šijací stroj), Sjartom, Sódár, Stuňịar, Šéf, Školňík, Škopịar, Štraygár, Štriker, Trombetáš, Truhlịiar, Účo, Viol'ína, Víšivkári.

8. Podl'a predmetov, rastlín a javov (7): Drína (názov cigariet), Fíl'er (filier, halier), Ford'ík (ako prvý mal automobil značky Ford), Gazda, Goréňe (žil v Slovinsku), Onajs (aníz), Št'etko.

9. Podl'a psycho-fyzických vlastností a stavov (45): Babura, Bajúz (dlhé fúzy), Baso (hlas ako basa), Béli, Bịel'i, Boží, Brzi, Buldok, Bure, Cigáňik, Cígo, Cŕni, Č́a'o, Čịerni, Drobní, Drndi, Drndo, Durilizňi, Ficko (chce sa fintit'), Gŕbo, Gríle (chce grílit'), Gróf, Guli, Hluchí, Hrịešni, Chruňo, Istina, Jumbo (džambo - vel'ký), Lucka, Mal'i, Mátoha, Mokram (mokrý - opilý), Novaploča, Papaj (gurmán), Pérostonoha, Pipili, Prtko, Pupči, Pústiňa, Radikál, Ruňo, Skoki (rýchly, šikovný), Šéfko, Točak, Žltý.

10. Podl'a kreslených a literárnych hrdinov, známych osobností a udalostí (17): Bádžo (animovaná postava), Bobek (animovaná postava), Degól (franc. Charles André Joseph Marie de Gaulle, 1890 - 1970, francúzsky štátnik), Fantóm (operná postava), Garibaldi (tal. Giuseppe Garibaldi 1807 - 1882, taliansky revolucionár), Kremenko (animovaná postava), Mičurím (rus. Иван Владимирович Мичурин; 1855 - 1935, ruský biológ) Paganini (tal. Niccolò Paganini, taliansky skladatel'), Pikaso (Pablo Picasso 1881 - 1973, španielsky maliar), Pižóm (Vladimir Petrović - Pižon, bývalý srbský futbalista), Roki (filmová postava), Sayčo (Sancho Panza - románová postava), Skubi (animovaná postava), Súrda (filmová postava), Tarzam (filmová postava), 
Vučko (vlk, maskot 14. zimných olympických hier v Sarajeve v roku 1984), Zágor (Zagor, komiksová postava).

11. Nezaradené (99): Báboš, Bigdžam, Bjášo, Brono, Bubi, Buro, Cáko, Čandúr, Čéčo, Čičko, Č́ze, Čordášoụci, Čúl'o, Čunčo, Čviro, Dad'i, Destri, Dodi, Drot'ko, Duto, Ď́do, Ď́iko, Ďusko, Ete, Fafro, Fati, Fífo, Fofi, Fuči, Gari, Hábenus, Héro, Hoši, Ikso, Jakara, Jóre, Káne, Kiki, Kokés, Krco, Kréjo, Kremči, Kŕle, Léve, Los, Leblii, Manci, Megre, Mino, Murgo, Nani, Naňi, Noki, Nuni, Ojo, Ol’o, Pace, Pacel', Pašt’o, Pil'o, Pini, Pipi, Pipík, Pipko, Piri, Piše, Pit’o, Pube, Pufta, Puriš, Raški, Regi, Rikso, Rinaldo, Róko, Rusti, Símo, Síro, Siso, Slíko, Šárgo, Šároši, Šišo, Škumškum, Šl'éko, Šmil'o, Šod'i, Šot'i, Špico, Šticko, Šuri, Taụžo, Trimček, Tŕto, Trupko, Túne, Ťot'i, Ťutii, Zvrndi.

\section{DATABÁZA ZAZNAMENANÝCH PRÍMEN V HLOŽANOCH ${ }^{3}$}

Hložany boli pôvodne sídlo so srbským obyvatel'stvom, kým roku 1756 sem neprišli Slováci. Hložany sú takmer čisto slovenské (Sirácky, 1980: 68). Na základe sčítania obyvatel'stva v roku 2012 podl'a Štatistického ústavu Republiky Srbsko v Hložanoch žilo spolu 2002 obyvatel'ov, z čoho bolo 1725 Slovákov.

Roztriedenie prímen:

1. Podl'a mena (úhrnne 86):

a) vyvodené z vlastného mena (28): Adamec, Andrés, Ďuki, Ďurika, Ďuro (2), Ferdo, Fero, Il’o, Jajo, Jánáš, Jayči, Janes, Janto, Jarinko, Jofko, Laur, Milo, Miškéc, Ojdo, Ol’o, Ond'it', Ondrejko, Onko, Pajco, Pako, Pavl'ík, Sájo.

b) vyvodené z priezviska (30): Bábel’a, Bábo, Benco, Crveňák, Dovi, Duliit, Frejki, Hrvoje, Gala, Geci (2), Júso, Kanás, Kat’o, Kika, Kul’a, Leukko, Loyci, Luko, Macák, Macík, Makso, Máto, Págo, Rečko, Rojce, Struško, Šul'am Tot'ko, Žáre.

c) podla srbského mena alebo priezviska (20): Bájit', Drágo, Gédžo, Gíle, Jóco, Jovánka, Jóvo, Kátit', Lázo, Míjo, Mít’o, Míle, Mírko, Mitre, Pájo, Péro (2), Sret'ko, Tíro, Žíko.

d) podla cudzieho mena (8): Hari, Janika, Jóška (2), Lajko, Palika, Tanaka, Žak.

${ }^{3}$ Anna Lovásová (rod. Korčoková; nar. 1939), Zuzana Korčoková (rod. Štefanidesová; nar. 1947), Jaroslav Makiš (nar. 1958) 
2. Podl’a geografického názvu, národného príslušenstva a priestorového rozmiestnenia (9): Bod’am, Ciprus, Harovčam, Sálašam, Srémac, Solúnac, šesto edom (podl'a čísla domu), V bịel'ej chiži, Žit.

3. Zvieracieho pôvodu (12): Bandár, Baram, Capár, Červíčok, Čížik, Grizlii, Pile, Ribadi, Šaš, Škorec, Škraňa, Ťurám.

4. Rodinného pôvodu (9): Apúško, Báto, Č́́ko, Síne, Sino, Sváko, Ujo, Ujko, Zat'ko.

5. Podl'a názvov jedál a nápojov (2): Bibera, Cukrík.

6. Cudzieho pôvodu (4): Bolám (bosnianska floskula), Faci (angl. face - tvár), Futuráš (angl. future - budúcnost'), Sandi (angl. sand - piesok).

7. Podl'a funkcie, zamestnania a vykonávania činnosti, názvu podniku (65): Apatịekár, Bačkoráš (2), Basista, Bovdáš, Brdár, Bríco, Bubár, Čád’o, Dekám, Dubinka, Glávoňa, Holịar (2), Holubịar, Hucko, Hud’ec, Husár, Husl'ičkár, Jáger, Kamenár, Kandrmáš, Kantor, Kapetám, Klonfer, Kochár, Kolovratár, Komunálac, Kováč, Kušňịar, L'eskár, Mašinist, Mesịar (2),Medár, Ml’inár, Moňašár, Opšivkár, Ovčịar, Pál’enňičịar, Paprikár (2), Pilana, Pisár, Píšt’alịiar, Policaj, Poungár (2), Preceda, Rajšplík, Repár, Saráč, Sekretár (2), Sódár (2), Statkár, Šnajder (2), Štriker, Šuster, Traksler, Trubač, Zmaj, Zvonár.

8. Podl'a predmetov, rastlín a javov (4): Breza, Lajsňa, Péršum, Tuturica.

9. Podl'a psycho-fyzických vlastností a stavov (40): Bachráč, Bohatý (3), Čịerňi, Čupko, Drahá duša, Drveni, Dugi, Gazda, Gora, Hluchí, Macane, Máli, Mal'í, Mrl’a, Mondén, Naidúci, Nočný fták, Obešeňịak, Pajtáš, Páyko, Papučkár, Pnňịaškár, Pint'o, Prt, Prd’am, Prndo, Rojčík, Sa-sa-sámko, Sopl'ík, Smejko, Sol'ídňi, Šed'iví, Šóňo, Šuhaj, Tajdi, Žalosni, Vinálesca.

10. Podl'a kreslených a literárnych hrdinov, známych osobností a udalostí (10): Bajaga (srbský spevák), Basara (Svetislav Basara - srbský spisovatel'), Beara (Vladimir Beara - bývalý fudbalista klubu Crvena Zvezda), Berger, Hošimin (viet. Hồ Chí Minh 1890 - 1969, vietnamský revolucionár a štátnik), Kuper (Bradley Charles Cooper, 1975, americký herec), Mrd’a (srbský hráć basketbalu), Pŕle (filmová postava zo srbského partizánskeho filmu), Šekulárac (Dragoslav Šekularac, bývalý srbský hráč fudbalu), Šíl’o (kreslená postava).

11. Nezaradené (72) Adi, Bad’o, Bégo, Bl'ano, Bondiš, Ceperi, Cul'a, Cvajko, Čarton, Ďidoụci, Doka, Dračo, Drusík, Duci, Ďumam, Džega, Fana, Giga, Golda, Gúle, Hampora (2), Híreš, Hula, Ištók, Jajo, Kajc, Keco, Kečke, Kedra, Komeš, Krajger, Krco, Krka, Laụšík, L'ibo, Lukaị, Makartúr, Mindo, Mirgeš, Mošo, Mugo, Pačko, Palotaj, Pándo, Pát', Pico, Piki, Piri, Pépo, Próko, Rani, 
Rat'ko, Red'o, Saraga, Sigaš, Solga, Sumo, Sasko, Siko, St'opko, Šégro, Šero, Šiško, Šoci, Š́́le, Šul'di (2), Šunto, Túbo, Zambo, Zebec.

\section{DATABÁZA ZAZNAMENANÝCH PRÍMEN V KULPÍNE ${ }^{4}$}

Kulpín patrí k najstarším slovenským osadám vo Vojvodine. Pôvodne tu žili Srbi. Niekol'ko slovenských poddanských rodín prišlo do Kulpína roku 1745, (ked' aj do Petrovca), no masovejšie nast'ahovanie Slovákov sa začalo po vydaní Tolerančného patentu cisárom Jozefom II. v roku 1781 (Sirácky, 1986: 68). Podl’a Štatistického ústavu Republiky Srbsko v roku 2012 v Kulpíne žilo spolu 2775 obyvatel'ov, z čoho bolo 1952 Slovákov.

Roztriedenie prímen.

1. Podl'a mena (úhrnne 41):

a) podla rodinného mena (5): Bábel'a, Dubec, Geci, Siroma, Štrba;

b) vyvodené z vlastného mena (14): Baki, Brance, Brendži, Dule, Gusti, Janci, Jovečko, Kít'o, Langa, Martinoụci, Mišenko, Pace, Petoụci, Zoro;

c) vyvodené z priezviska (18): Bene, Čéko, Čiki, Faki, Hále, Jogi, Kóle, Kuki, Médo, Peki, Pucko, Smíle, Šeki,Trps, Virdži, Zaki, Zél'o, Zoki;

d) podl'a srbského mena/priezviska (4): Bájit', Dúle, Sále, Žíko;

2. zvieracieho pôvodu (1): Zajac;

3. cudzieho pôvodu (2): Ból’šo (rus. большой - Vel'ký), Karajánko (tur. Čierny Janko);

4. podl’a funkcie, zamestania (25): Bubnáš, Col’i/Col’o (cól alebo palec je staršia dížková miera), Darál'oš, Ďebnár, Devízňi (dostával nemecký dôchodok, „devize”), Džandár, El'etričịar, Kováč, Mesịar, Muzikant, Počtár, Páleňičịiar, Rančer (vlastniaci „ranč”, salaš), Richtár, Saráč (vyrábali remene), Sódár, Starejší, Šuster (obuvník), Školňík, Pope (v tomto prípade „pán starejší”), Trst'inkár, Učitel', Účo, Veterinár, Vulkanizér;

5. podl’a psycho-fyzických vlastností a stavov (6): Bel'aví, Bŕko, Jápo (podobá sa na Japonca), Kinés (podobá sa na Číňana), Medeni (,sladký” ako med), Šlivi (majúci rád slivovicu).

6. Nezaradené (19): Burdo, Čibora, Činči, Čúne, Gošo, Gubečka, Múdžo, Mrčko, Panci, Prišoụci (prišli, dost'ahovali sa), Pujke, Púle, Rúžo, Sisko, Sprdži, Sturi, Šifel’a, Šifi, Škofec.

4 Informátori: Anna Bovdišová (nar. 1944), Anna Melichová (nar. 1954), Alexandra Bovdišová (nar. 1995), Jana Domoniová (nar. 1995) 


\section{ZÁVERY}

V príspevku sme brali ohl'ad na skutočnost', že na prímeno, ktoré sprevádza určitú osobu v lokálnom prostredí počas celého života, l’udia neraz emočne reagujú. Preto sme pri zaznamenávaní prímen vylúčili tie, pri ktorých sme zistili, že sú negatívne ponímané osobou alebo rodinnými príslušníkmi. Prímená sme nedávali do súvisu s priezviskami z objektívnych príčin. Pri uvádzaní prímen sme použili tie isté kategórie, ako aj v predchádzajúcom výskume (Marčoková, Makišová, 2017). Použili sme fonetickú transkripciu kvôli tomu, aby sa prímená mohli správne prečítat'. Pri niektorých prímenách v zátvorke sme uviedli aj okolnosti, v ktorých vznikli. Srbské prímená sme nepovažovali za slová cudzieho pôvodu, lebo vojvodinskí Slováci sú bilingvisti a v úplnosti im rozumejú.

Prímená sú typické pre malé sociálne skupiny, kam patria aj skúmané dedinské komunity. Čím je však osada menšia, prímen je pochopitel'ne menej aj z toho dôvodu, že postačujúcu identifikačno-diferenciačnú funkciu tu majú krstné meno a priezvisko. Najviacej prímen sme zaznamenali v Báčskom Petrovci: pri 181 priezviskách bolo úhrnne 432 prímen (najviac prímen mali priezviská: Spevák, Kopčok a Melich); v Hložanoch sme pri 101 priezviskách zaznamenali 299 prímen (Kukučka, Stupavský a Molnár boli priezviská s najväčším počtom prímen); v Kulpíne sme pri 37 priezviskách zaznamenali 94 prímen (najviac prímen mali priezviská: Šimo, Vida, Valentík a Zima).

V každej osade bolo najviac prímen vyvodených $\mathrm{Z}$ vlastného mena a priezviska $^{5}$ (BP: 187, H: 77, K: 94). Potom podl'a funkcie, zamestnania a vykonávania činnosti (BP: 57, H: 53, K: 25), podl'a psycho-fyzických vlastností a stavov (BP: 43, H: 38, K: 6) atd'. Hodne bolo aj prímen, ktoré sme nevedeli kategorizovat' (BP: 101, H: 86, K: 19).

Pre každú vojvodinskú lokalitu, v ktorej žijú Slováci, sú príznačné iné priezviská, no vychádzali sme z predpokladu, že prímená týkajúce sa zamestnania, sa vyskytujú v rovnakej podobe v každej slovenskej vojvodinskej osade. Zistili sme, že iba jedno prímeno označujúce zamestnanie sa vyskytlo vo všetkých troch osadách (Sódár). Nasledujúce prímená sa vyskytli v dvoch osadách: Brdár (BP, H), Darálovník/Darál’oš $\quad(B P, \quad K), \quad$ Dekam/Dekám $\quad(B P, \quad H), \quad$ Huci/Hucko, Hud'ec/Muzikant (BP, H, K), Kemenári/Kemenár (BP, H), Kolovratár (BP, H), Kováč $(H, K)$, Kušňịar (BP, H), Mesịar (H, K), Paprikár (BP, H), Pál'enňičịar (H,

${ }^{5}$ Pri uvádzaní príkladov používame skratky: BP (Báčsky Petrovec), H (Hložany), K (Kulpín). 
K), Školňík (BP, K), Štriker (BP, H), Šuster (H, K), Účo (BP, K). V niektorých prímenách je zachované svedectvo o zamestnaniach, ktoré zanikajú: Bačkoráš $(H)$, Brdár (BP), Bubár (H), Holịar (H), Kolovratár (BP, H), Kováč (H, K), Kušňịar (BP, H), Lojtráš (BP), Mlinár (H), Starejší (K), Štrangár (BP).

Všimli sme si príklon k cudzím slovám. Najčastejšie sa preberajú z angličtiny a to osobné mená: Čarli (BP), Džeki (BP), Džoni (BP), Laki (BP). Zaznamenali sme aj niektoré inojazyčné prímená: z mad’arčiny: Ištván (BP), Juhás (BP), Pišta (BP); z nemčiny: Johan (BP); zo španielčiny: Migel (BP); zo slovinčiny: Janes (BP); z chorvátčiny: Stípe (BP); z ruštiny: Ból'šo(K); z turečtiny: Karajánko $(\mathrm{K})$.

Boli prípady, ked' jedna osoba mala dve prímená: Šošana/Šošón (BP), Paganini/Violína (BP). V Báčskom Petrovci sme zaznamenali prípady, ked' sa prímeno vzt'ahovalo na niekol'ko osôb toho istého alebo rozličného priezviska. $\mathrm{V}$ zátvorke uvádzame ich počet: Bábo (2), Bádžo (2), Bene (2), Bịeli (2), Brzi (2), Čịerni (3), Drndi (2), Džeki (2), Džoni (3), Herec (2), Hluchí (2), Kóle (3), Kóro (2), Kuki (2), Laki (2), Máko (2), Makso (2), Márko (2), Očko (2), Rápo (2), Roki (3), Siki (3), Siso (2), Sjartom (2), Šaňi (3), Šubi (2), Viol'ína (2).

Ked’že sa vo všetkých osadách rozpráva stredoslovenským nárečím, na základe prímen nemôžeme určit', z ktorej osady pochádzajú. Niekedy sa pri tvorbe prímen nerešpektuje rytmický zákon, čo považujeme za vplyv nárečia (Sklíčkár, Sódár, Peňịaškár, Apat’iekár). Slováci v týchto osadách spolunažívajú so srbským obyvatel'stvom, takže sú niektoré prímená ovplyvnené srbčinou: Glávoňa $(\mathrm{H})$, Istina (BP), Komunálac (H), Medeni (K), Pope (K), Pústiňa (BP), Točak (BP). Zaznamenali sme iba jedno prímeno, ktoré poukazuje na slovenský etnický pôvod: Slovák (BP). Niekedy sa prímená dali zaradit' aj do dvoch kategórií, takže bolo treba zvážit' okolnosti vzniku jednotlivých prímen. Hoci sa jednočlenné prímená vyskytujú najčastejšie, zaznamenali sme i dvojčlenné: Drahá duša $(H)$, Duurilizňi $(\mathrm{H})$, Nočný fták (H), Nova ploča (BP), Péro stonoha (BP), Pipi doktor (BP), a jedno trojčlenné prímeno: $\mathrm{V}$ bịel'ej chiži $(\mathrm{H})$.

Podl'a posledného súpisu Štatistického ústavu Republiky Srbsko z roku 2011, v Srbsku žilo 52750 Slovákov $^{6}$. V súčasnosti je t’ažko určit' presný počet obyvatel'ov slovenskej národnosti v Srbsku kvôli súčasným pohybom obyvatel'stva, t. j. novodobým migráciám. Predpokladáme, že tento jav spolu so súčasným negatívnym prirodzeným prírastkom bude $\mathrm{v}$ budúcnosti vplývat' na zmenšenie

\footnotetext{
${ }^{6}$ Republički zavod za statistiku. Dostupné na: http://webrzs.stat.gov.rs/WebSite/Public/ ReportResultView.aspx?rptId=1210
} 
počtu príslušníkov slovenskej národnostnej menšiny vo Vojvodine. Nazdávame sa, že naša práca bude prínosná v zmysle zachovania svedectva o časoch, ked' tu žili Slováci vo väčšom počte. Pri našom výskume všetci oslovení informátori prejavili prirodzený záujem a ochotne sa zapojili do zhromažd’ovania údajov. Ba čo viac, prímená vo všetkých skúmaných prostrediach zaujali širokú laickú verejnost', čo v nás iba upevnilo presvedčenie, že treba pokračovat' vo výskume prímen v Báčke, ale i v Banáte a v Srieme.

Daniela Marčoková, Ana Makišová

NICKNAMES OF SLOVAKS IN SLOVAK SETTLEMENTS IN THE COUNTY OF BAČKI PETROVAC

\section{Summary}

The appearance of nicknames is a thriving sociolinguistic process with an important historical factor. Our goal was to record the nicknames found in the living memories of the current, ethnically-Slovak inhabitants of Bački Petrovac, Gložan and Kulpin.

The results of our investigation can be summarized as follows: in Bački Petrovac we recorded 432 nicknames from 181 last names, in Gložan 299 nicknames were recorded from 101 lastnames, and in Kulpin 94 nicknames from 37 last names. Some families with many branches in these Slovak villages have up to 20 nicknames. Even though one-word nicknames are most frequent, we also recorded two-word and three-word nicknames. There are cases where one person has two nicknames and vice versa, in which one nickname sometimes refers to several people. The giving of nicknames is often influenced by both the Central Slovak dialect spoken in all three villages and Serbian, which is the region's official language. We also recorded nicknames given on the basis of first names from other langauges. The majority of nicknames were derived from personal first and last names (the total from all three villages: 358), the next largest group of nicknames were based on function, employment, or practice (total: 135), the next group were based on psychophysical characteristics and states (87), and so on.

Nicknames in a way reflect the history of these villages and thus characterize the way of life of people living in certain times and localities with all their local and regional specifics. In Bačka, the census records a long and ongoing decline in the population of the Slovak speaking national minority. Therefore, we find that recording nicknames is part of preserving an important, non-material cultural and traditional heritage.

Key words: onomastic; nicknames of Slovaks in the villages of Bački Petrovac, Gložan and Kulpin; cultural and traditional specificity at "Southern Land” 
Daniela Marčok, Ana Makišova

NADIMCI SLOVAKA U SLOVAČKIM NASELJIMA BAČKOPETROVAČKE OPŠTINE

\section{Sažetak}

Nastanak nadimaka je živ sociolinvistički proces sa važnim istorijskim faktorom. Naš cilj je bio da zabeležimo nadimke koji su ostali sačuvani u živom sećanju sadašnjih stanovnika slovačke nacionalnosti u Bačkom Petrovcu, Gložanu i Kulpinu.

Rezultate našeg istraživanja možemo da sažmemo na sledeći način: u Bačkom Petrovcu smo kod 181 prezimena zabeležili 432 nadimka; u Gložanu je bilo zabeleženo 299 nadimaka kod 101 prezimena, a u Kulpinu je bilo 94 nadimka kod 37 prezimena. Neke razgranate porodice u ovim slovačkim selima imaju i do 20 nadimaka. Iako su jednočlani nadimci najčešći, zabeležili smo i dvočlane i tročlane nadimke. Postoje slučajevi kada jedna osoba ima dva nadimka i suprotno - jedan nadimak se ponekad odnosi na nekoliko osoba. Davanje nadimaka je često pod uticajem srednjeslovačkog dijalekta kojim se govori u sva tri sela, kao i pod uticajem srpskog jezika kao prvog službenog jezika zemlje. Zabeležili smo i nadimke date na osnovu inojezičnih ličnih imena. Najviše je bilo nadimaka izvedenih iz vlastitog imena i prezimena (u sva tri sela ukupno 358), zatim nadimaka na osnovu funkcije, zaposlenja ili vršenja delatnosti (ukupno 135), na osnovu psiho-fizičkih osobina i stanja (87) itd.

Nadimci na određen način reflektuju istoriju naših sela i na taj način karakterišu način života ljudi određenog doba i lokaliteta sa svim njihovim lokalnim i regionalnim specifičnostima. U popisima stanovništva Bačke dugoročno beležimo smanjenje broja pripadnika slovačke nacionalne manjine. Stoga smatramo da je beleženje nadimaka značajno nematerijalno kulturno i tradicionalno, nasleđe.

Ključne reči: onomastika, nadimci Slovaka u selima Bački Petrovac, Gložan, Kulpin; kulturna i tradicionalna specifičnost na Donjoj zemlji.

\section{LITERATÚRA}

Blanár, V. (2008). Vlastné meno vo svetle teoretickej onomastiky. Bratislava: JULS SAV.

Botík, J. (2011). Dolnozemskí Slováci. Nadlak: Vydavatel'stvo Ivan Krasko.

Csachová, S. (2015). Priezvisko v humánno-geografickom výskume - prípad okresu Košice-okolie. Geographia Cassoviensis, IX/2, 100-107.

Ćirković, S. (2015). Nadimci starih Beograđana: 1830-1940. Beograd: Službeni glasnik.

Dudok, D. (1998). Priezviská Slovákov v Juhoslávii. Nový Sad: Spolok vojvodinských slovakistov. 
Kováč, J. (2002). Priezviská Slovákov v Starej Pazove. Stará Pazova: vlastným nákladom.

Krátky slovník slovenského jazyka (1989). Bratislava: Veda, vydavatel'stvo Slovenskej akadémie vied.

Marčoková, D., Makišová, A. (2017). Prímená v Kysáči ako kultúrne a tradičné dedičstvo. In: Andrić, E., Smiljanić, D. (ed.) Godišnjak Filozofskog fakulteta u Novom Sadu, XLII-1, Novi Sad: Filozofski fakultet. 291-303.

Marićová, A. (2014). Neúradné priezvisko vo funkcii živého mena u staropazovských Slovákov. In: Gudurić, S., Stefanović, M. (ed.) Jezici $i$ kulture u vremenu i prostoru, IV/1, Novi Sad: Filozofski fakultet. 79-86.

Párnický, M. (s.a.). Kysáčske nádymky (rukopis).

Pehrat, V., Antonić, (2012). Nadimci u Donjoj Vrbavi kao kulturno i tradicionalno nasleđe. Gornji Milanovac: Muzej rudničko-takovskog kraja.

Synonymický slovník slovenčiny (2004). Bratislava: Veda, vydavatel'stvo Slovenskej akadémie vied.

Sirácky, J. (1980). Slováci vo svete 1. Martin: Matica slovenská.

Sklabinská, M., Mosnáková, K. (ed.) (2012). Slováci v Srbsku z aspektu kultúry. Nový Sad: Ústav pre kultúru vojvodinských Slovákov.

Týrová, Z. (2005). Prezývky Slovákov v obci Pivnica (Juhoslávia). In: Šimková, M. (ed.) Varia XII. Zborník materiálov z XII. kolokvia mladých jazykovedcov (Modra - Piesok 4. -6. 12. 2002). Bratislava: Slovenská jazykovedná spoločnost' pri SAV. 175-179. 